\title{
The Use Of Polyurethane Transparent Film In Indwelling Central Venous Catheter
}

\author{
Renata Cristina de Campos Pereira Silveira ${ }^{1}$ \\ Fernanda Titareli Merizio Martins Braga² \\ Livia Maria Garbin² \\ Cristina Maria Galvão ${ }^{3}$
}

\begin{abstract}
Dressing is an intervention aimed to prevent infection in central venous catheter. This study aimed to analyze the frequency of catheter-related infection and skin toxicity in the use of transparent film in Hickman's catheter in patients who underwent allogeneic hematopoietic stem cell transplantation. A case series with 10 cases was carried out. Due to the presence of exudate on the average for 12 days, sterile gauze dressing was used for 12.9 days (average). Transparent film was used, on average, for 15.1 days. Catheters were precociously removed due to infection in four cases. The highest degree of skin toxicity occurred in a case that used gauze dressing and in three cases with film. The transparent film permitted visualization of the exit site of the catheter and changes with longer intervals.

Descriptors: Hematopoietic Stem Cell Transplantation; Bone Marrow Transplantation; Catheterization, Central Venous; Bandages; Occlusive Dressings.
\end{abstract}

\footnotetext{
${ }_{1}^{1}$ Article extracted from Doctoral Dissertation "Filme transparente de poliuretano: evidências para a sua utilização no curativo de cateter venoso central de longa permanência", presented to Escola de Enfermagem de Ribeirão Preto, Universidade de São Paulo, WHO Collaborating Centre for Nursing Research Development, SP, Brazil. Supported by Programa de Apoio à Pós-graduação, Coordenação de Aperfeiçoamento de Pessoal de Nível Superior (PROAP-CAPES).

${ }^{2}$ RN, Ph.D. in Nursing, Professor, Escola de Enfermagem de Ribeirão Preto, Universidade de São Paulo, SP, Brazil. E-mail: recris@eerp.usp.br.

${ }^{3}$ RN, Escola de Enfermagem de Ribeirão Preto, Universidade de São Paulo, SP, Brazil. E-mail: Fernanda - titareli@eerp.usp.br, Livia - liviagarbin@usp.br.

${ }^{4}$ RN, Ph.D. in Nursing, Associate Professor, Escola de Enfermagem de Ribeirão Preto, Universidade de São Paulo, SP, Brazil. E-mail: crisgalv@eerp.usp.br.
}

Corresponding Author:

Renata Cristina de Campos Pereira Silveira

Universidade de São Paulo. Escola de Enfermagem de Ribeirão Preto.

Departamento de Enfermagem Geral e Especializada.

Av. Bandeirantes, 3900, Campus Universitário

Bairro Monte Alegre

CEP: 14040-902 Ribeirão Preto, SP, Brasil.

E-mail: recris@eerp.usp.br 


\section{O uso do filme transparente de poliuretano no cateter venoso central de longa permanência}

O curativo é intervenção que visa a prevenção de infeç̧ão no cateter venoso central. O estudo teve como objetivo analisar a frequência de infecção, relacionada ao cateter, e toxicidade cutânea, na utilização do curativo de poliuretano no cateter de Hickman, implantado em pacientes submetidos ao transplante de células-tronco hematopoéticas alogênico. Para tal, realizou-se uma série de casos, constituída por 10 casos. 0 exsudato esteve presente em média por 12 dias, sendo necessário o uso do curativo de gaze estéril, com fita adesiva, por 12,9 dias (média). O curativo de poliuretano foi utilizado, em média, por 15,1 dias. A retirada precoce do cateter por infecção ocorreu em quatro casos. O maior grau de toxicidade cutânea aconteceu em um caso que utilizou o curativo de gaze e em três casos com filme. O filme transparente permitiu a visualização do sítio de saída do cateter e a troca com intervalos maiores.

Descritores: Transplante de Células-Tronco Hematopoéticas; Transplante de Medula Óssea; Cateterismo Venoso Central; Bandagens; Curativos Oclusivos.

\section{Uso de la película transparente de poliuretano en el catéter venoso central de larga permanencia}

El curativo es una intervención que tiene por objetivo la prevención de infección en el catéter venoso central. El estudio tuvo como objetivo analizar la frecuencia de infección relacionada al catéter y la toxicidad cutánea en la utilización del curativo de poliuretano en el catéter de Hickman implantado en pacientes sometidos al trasplante de células tronco hematopoyéticas alogénicas. Para esto se realizó una serie de 10 casos. El exudado estuvo presente en promedio por 12 días, siendo necesario el uso del curativo de gasa estéril con cinta adhesiva por 12,9 días (promedio). El curativo de poliuretano fue utilizado en promedio por 15,1 días. La retirada precoz del catéter debido a surgimiento de infección ocurrió en cuatro casos. El mayor grado de toxicidad cutánea ocurrió en un caso que se utilizó el curativo de gasa y en tres casos que utilizaron la película. La película transparente permitió la visualización del sitio de salida del catéter y la realización del cambio en intervalos mayores.

Descriptores: Trasplante de Células Madre Hematopoyéticas; Trasplante de Médula Ósea; Cateterismo Venoso Central; Vendajes; Apósitos Oclusivos.

\section{Introduction}

The surgical implantation of an indwelling central venous catheter (CVC) is needed to perform hematopoietic stem cell transplantation (HSCT), and Hickman's catheter is indicated for most patients. That is the first preparatory action for HSCT, but the catheter's presence can cause complication, including infection caused by the rupture of the patient's skin integrity, which can lead to death(1-3).

Placing a dressing on the CVC exit site aims to reduce catheter-related infection. A wide range of materials is used as CVC dressing. Literature reports on the use of the following materials: sterile gauze with adhesive tape, transparent polyurethane film, highly transpiration moisture permeable transparent polyurethane film and hydrocolloid dressing(4-6).

Among advantages appointed for the use of transparent polyurethane film in indwelling catheter dressings for HSCT patients, longer dwelling time stands out, decreasing skin irritation manifested through local injuries, which cause discomfort and pain during dressing 
change. Besides this aspect, there is evidence of greater satisfaction and better comfort from the patient's perspective, material cost reduction and decreased needs for the nursing team ${ }^{(7-9)}$.

Despite these advantages, literature presents disagreement on the efficacy of transparent film. Some studies ${ }^{(6,10-11)}$ evidenced no difference in infection incidence levels when comparing this type of dressing with the use of sterile gauze. Other studies ${ }^{(4,12-13)}$, on the other hand, appointed increased incidence of CVC-related infection when polyurethane dressings are used.

In Brazilian literature, two randomized and controlled clinical trials assessed the use of polyurethane dressing, but in peripheral venous catheters. In both studies, pediatric patients were divided in three groups: transparent film, sterile gauze and adhesive tape and hypo-allergenic adhesive tape alone ${ }^{(14-15)}$.

One study aimed to analyze the influence of the dressing type on the dwelling time of peripheral venous catheters. Its results appointed that the group that used sterile gauze dressings and adhesive tape showed a longer dwelling time for the device ${ }^{(14)}$. The other study identified the reasons for removal and adverse events related to the use of peripheral intravenous catheters in children according to the dressing types. The results demonstrated a statistically significant difference in the group with sterile gauze and adhesive tape regarding the decrease of adverse events like phlebitis, infiltration, folding of the device and accidental removal(15).

It should also be highlighted that studies described in international literature ${ }^{(4-13)}$ were conducted with funding from the pharmaceutical industry and in countries with a moderate climate. Thus, this study aims to assess the use of polyurethane dressing in Hickman's catheter in hospitalized patients in a tropical country with a warm and humid climate. This unedited research arouses concerns regarding the climate's possible influence on the dressing type's performance. This concern was also identified in Brazilian studies ${ }^{(14-15)}$.

In view of the divergences detected in literature and the lack of Brazilian research, this study was conducted to develop research resulting in significant contributions to clinical nursing practice.

\section{Aim}

To analyze the frequency of catheter-related infection and skin toxicity in the use of polyurethane dressing on the exit site of Hickman's catheter implanted in allogeneic HSCT patients.

\section{Material and method}

This is a case series, which is a methodological option to test products or procedures. In this design, the sample is not randomly allocated and no control group is constituted, which makes it difficult to isolate the effect of the research intervention. The evidenced results can be confronted with literature, however, and provide evidence on the use and safety of the product or procedure under assessment ${ }^{(16)}$.

The study was carried out at an allogeneic HSCT hospitalization unit in a general public hospital in the interior of São Paulo State. Regarding inclusion criteria, the sample comprised subjects in the age range of 16 years or older; who were candidates for related allogeneic HSCT, involving the infusion of hematopoietic stem cells from bone marrow and peripheral blood, and surgically implanted Hickman's catheter under aseptic conditions at the surgical center.

Subjects were excluded who expressed a previous adverse reaction to the polyurethane dressing; with active skin injuries; with bacteremia or fungemia within 14 days before the start of data collection, as this is the expected period to solve these complications after the start of adequate treatment, and/or had a short-term central venous catheter implanted.

The six nurses who worked at the unit, together with one of the researchers, observed the research subjects daily and assessed the study variables. Therefore, they were trained, using the teaching program strategy.

Initially, a pre-test was performed with multiple choice questions on the following items: CVC dressing procedure technique, characteristics of different coverage types, way to apply and remove the transparent film, signs and symptoms of CVC-related infection and skin toxicity. After applying the pre-test among the nurses, the responsible researcher gave a presentation on the contents of the pre-test and demonstrated how to use the transparent film. At the end of the class, the nurses were asked to answer the questionnaire again, which was called post-test. Nurses who scored at least $80 \%$ on the post-test were considered apt to start data collection. It should be highlighted that the mean score on the pre-test was $86.6 \%$, against $92.5 \%$ on the posttest, showed that all nurses reached the cut-off score already on the pre-test.

For data collection, an instrument was elaborated with information regarding subjects' characteristics; the conditioning regimen, that is, the chemotherapeutic 
agents used for bone marrow aplasia and whether associated with radiotherapy or not; date of transplantation; number of dressings applied; type of coverage used; and signs and symptoms of infection according to Centers for Disease Control and Prevention $(C D C)^{(17)}$ guidelines and of skin toxicity.

The instrument was submitted to face and content validation by four experts (nurses, two with professional experience in care to HSCT patients and two active in teaching, research and community service at a public state university). The experts suggested some modifications in the way the items were presented, which the researchers accepted.

The independent variable was the OpSite ${ }^{\circledR}$ polyurethane dressing, with changes programmed every seven days. Dependent variables were: skin toxicity and CVC-related infection. Skin toxicity was assessed as degree 1 - presence of macula, papule or erythema, asymptomatic; degree 2 - presence of macula, papule or erythema, with itch or other local associated symptoms; degree 3 - presence of macula, papule or bladder surpassing the borders of the dressing and degree 4 - presence of exfoliative or ulcerative dermatitis ${ }^{(8)}$. The CVC-related infection was divided in exit site infection; tunnel infection and catheter-related bloodstream infection, which needs to be confirmed by a blood culture results, according to the CDC classification ${ }^{(17)}$.

Data were collected between August 2007 and July 2008. The nurses and the responsible researcher applied the dressing as follows: after the implantation of Hickman's catheter, all patients used the sterile gauze dressing fixed with adhesive tape until the exudate ceased; skin antisepsis was performed in three clockwise movements with sterile gauze drenched in $0.5 \%$ alcohol-chlorhexidine. In case of exudate, sterile gauze was used, fixed with thin adhesive type and changed daily. When no exudate was present, transparent polyurethane film was used (OpSite ${ }^{\circledR}$ IV 3000), with changes programmed every 7 days. The presence of exudate after the implant is due to the surgical wound healing process, which starts with the inflammatory or exudative phase, taking between four and six days. The accumulation of exudate below the dressing is a source of concern, due to the risk of local proliferation of microorganisms ${ }^{(18)}$.

The trained nurses assessed signs and symptoms of skin toxicity daily at the dressing adhesion site and, in case of differences from the previous day, the data were confirmed through the responsible researcher's observation. The trained nurses observed signs and symptoms of CVC-related infection daily. Every day, the responsible researcher consulted laboratory results of complete blood counts, blood cultures and skin cultures in the patients' files and data the nurses recorded on the data collection instrument during daily clinical assessment for the classification of the catheter-related infection type.

Data were analyzed descriptively, using statistical measures like arithmetic means, standard deviation, median, minimum and maximum.

Approval for this research was obtained from the Research Ethics Committee at the University of São Paulo at Ribeirão Preto Medical School Hospital das Clínicas on February 28 2007 (protocol No 14222/2006). All study participants signed the Free and Informed Consent Term after the researcher had provided information on the research goals, highlighting that they could cease participating at any time, without any kind of risk or harm.

\section{Results}

The sample comprised 10 subjects, six (60\%) women and four (40\%) men. The average age was 41.9 years, ranging from 16 to 57 years. With regard to the baseline disease, four patients had leukemia, three myelodysplastic syndrome, two severe aplastic anemia and one Blackfan Diamond syndrome. Three deaths (30\%) occurred during the hospitalization period. The median time passed between diagnosis and HSCT was eight months, ranging between two and 504 months. The conditioning regimen fludarabine and busulphan was used in five cases, and the drug busulphan in seven cases. 
Table 1 - Case distribution according to number of assessed days, days with exudate, number of days with sterile gauze and polyurethane dressings, time between surgical implant of central venous catheter and start of conditioning regimen, Ribeirão Preto, 2007-2008

\begin{tabular}{|c|c|c|c|c|c|}
\hline Case & $\begin{array}{l}\text { Assessment } \\
\text { (days) }\end{array}$ & Exudate (days) & $\begin{array}{l}\text { Gauze and adhesive } \\
\text { tape (days) }\end{array}$ & Polyurethane (days) & $\begin{array}{l}\text { Surgical implant of central venous catheter } \\
\text { and conditioning regimen (hours) }\end{array}$ \\
\hline 1 & 22 & 10 & 16 & 06 & 20 \\
\hline 2 & 37 & 18 & 18 & 19 & 12 \\
\hline 3 & 34 & 25 & 24 & 10 & 36 \\
\hline 4 & 39 & 15 & 16 & 23 & 192 \\
\hline 5 & 36 & 10 & 11 & 25 & 48 \\
\hline 6 & 20 & 05 & 07 & 13 & 18 \\
\hline 7 & 12 & 09 & 09 & 03 & 72 \\
\hline 8 & 25 & 17 & 17 & 08 & 24 \\
\hline 9 & 28 & 03 & 03 & 25 & 48 \\
\hline 10 & 27 & 08 & 08 & 19 & 48 \\
\hline Total & 280 & 120 & 129 & 151 & 518 \\
\hline Mean & 28 & 12 & 12.9 & 15.1 & 51.8 \\
\hline $\mathrm{SD}^{*}$ & 8.61 & 6.68 & 6.33 & 8.15 & 52.5 \\
\hline
\end{tabular}

* Standard Deviation

** Time between surgical implant of central venous catheter and start of conditioning regimen

In Table 1, it is observed that the CVC was assessed for periods ranging from 12 to 39 days, with a mean 28 days, totaling 280 observations. Exudate was present for an average 12 days, entailing the need to use sterile gauze dressings with adhesive tape for 12.9 days (mean). Polyurethane dressings were used for an average 15.1 days. The time between the surgical implant of the CVC and the start of the conditioning regimen ranged from 12 to 192 hours, with a mean 51.8 hours, that is, on the average, the conditioning regimen started two days after the implant.

Table 2 - Case distribution according to additional dressing change and cutaneous toxicity degree. Ribeirão Preto, 2007-2008

\begin{tabular}{|c|c|c|c|c|}
\hline \multirow[b]{2}{*}{ Case } & \multicolumn{2}{|c|}{ Frequency } & \multicolumn{2}{|c|}{ Cutaneous toxicity degree } \\
\hline & $\begin{array}{l}\text { Additional change gauze } \\
\text { and adhesive tape }\end{array}$ & $\begin{array}{l}\text { Additional change } \\
\text { polyurethane }\end{array}$ & $\begin{array}{l}\text { Cutaneous toxicity gauze } \\
\text { and adhesive tape }\end{array}$ & $\begin{array}{l}\text { Cutaneous toxicity } \\
\text { polyurethane }\end{array}$ \\
\hline 1 & 0 & 5 & - & degree 4 \\
\hline 2 & 0 & 0 & degree 4 & - \\
\hline 3 & 0 & 1 & degree 1 & degree 2 \\
\hline 4 & 0 & 1 & - & degree 1 \\
\hline 5 & 0 & 1 & - & degree 4 \\
\hline 6 & 0 & 2 & - & - \\
\hline 7 & 0 & 0 & - & - \\
\hline 8 & 1 & 0 & - & - \\
\hline 9 & 0 & 3 & - & degree 4 \\
\hline 10 & 0 & 2 & - & - \\
\hline Total & 1 & 15 & - & - \\
\hline Mean & 0.10 & 1.50 & - & - \\
\hline $\mathrm{SD}^{*}$ & 0.31 & 1.58 & - & - \\
\hline
\end{tabular}

*Standard Deviation

Additional change of the sterile gauze dressing with adhesive tape was necessary once; in the polyurethane dressing, on the other hand, additional changes occurred 15 times (Table 2). The mean additional change of the sterile gauze dressing with adhesive tape was 0.1 times, against 1.5 times for the polyurethane dressing. In three cases, no additional change of the polyurethane dressing was needed. Hence, despite the need for additional change in seven cases, in comparison with the daily gauze dressing change, the dwelling time of the film dressing was longer. 
Skin toxicity was more frequent during the use of transparent polyurethane film, with three degree-4 cases. On the opposite, only one case developed degree-4 skin toxicity during the use of sterile gauze dressing with adhesive tape.

Table 3 - Case distribution according to characteristics of central venous catheter exit site, surgery duration, neutropenia, reason for withdrawal and dwelling of removed central venous catheter. Ribeirão Preto, 2007-2008

\begin{tabular}{|c|c|c|c|c|c|c|c|c|}
\hline Case & $\begin{array}{c}\text { Erythema } \\
\leq 2 \mathrm{~cm} \text { (days) }\end{array}$ & $\begin{array}{c}\text { Erythema } \\
>2 \mathrm{~cm} \text { (days) }\end{array}$ & $\begin{array}{c}\text { Edema } \\
\leq 2 \mathrm{~cm} \text { (days) }\end{array}$ & $\begin{array}{c}\text { Edema } \\
>2 \mathrm{~cm} \text { (days) }\end{array}$ & $\begin{array}{c}\text { Pain } \\
\leq 2 \mathrm{~cm} \text { days })\end{array}$ & $\begin{array}{c}\text { Pain } \\
>2 \mathrm{~cm} \text { (days) }\end{array}$ & $\begin{array}{c}\text { Heat } \\
\leq 2 \mathrm{~cm} \text { (days) }\end{array}$ & $\begin{array}{c}\text { Heat } \\
>2 \mathrm{~cm} \text { days) }\end{array}$ \\
\hline 1 & 20 & 1 & 3 & 0 & 0 & 0 & 0 & 0 \\
\hline 2 & 17 & 0 & 2 & 0 & 2 & 0 & 0 & 0 \\
\hline 3 & 0 & 0 & 0 & 0 & 0 & 0 & 0 & 0 \\
\hline 4 & 22 & 0 & 0 & 0 & 0 & 0 & 0 & 0 \\
\hline 5 & 0 & 0 & 7 & 0 & 0 & 0 & 0 & 0 \\
\hline 6 & 15 & 0 & 2 & 0 & 0 & 0 & 2 & 0 \\
\hline 7 & 8 & 1 & 10 & 1 & 0 & 12 & 0 & 1 \\
\hline 8 & 8 & 0 & 0 & 0 & 1 & 1 & 0 & 0 \\
\hline 9 & 27 & 0 & 2 & 0 & 2 & 0 & 0 & 0 \\
\hline 10 & 18 & 0 & 0 & 0 & 0 & 0 & 0 & 0 \\
\hline Total & 135 & 2 & 26 & 1 & 5 & 13 & 2 & 1 \\
\hline Mean & 13.5 & 0.2 & 2.6 & 0.1 & 0.5 & 1.3 & 0.2 & 0.1 \\
\hline $\mathrm{SD}^{* *}$ & \pm 9.16 & \pm 0.42 & \pm 3.37 & \pm 0.31 & \pm 0.84 & \pm 3.77 & \pm 0.42 & \pm 0.31 \\
\hline Case & \multicolumn{2}{|c|}{ Surgery duration (minutes) } & \multicolumn{2}{|c|}{ Neutropenia (days) } & \multicolumn{2}{|c|}{ Reason CVC* withdrawal } & \multicolumn{2}{|c|}{ Dwelling removed CVC (days) } \\
\hline 1 & \multicolumn{2}{|c|}{30} & \multicolumn{2}{|c|}{21} & \multicolumn{2}{|c|}{ ISS } & \multicolumn{2}{|c|}{22} \\
\hline 2 & \multicolumn{2}{|c|}{110} & \multicolumn{2}{|c|}{23} & \multicolumn{2}{|c|}{-} & \multicolumn{2}{|c|}{-} \\
\hline 3 & \multicolumn{2}{|c|}{30} & \multicolumn{2}{|c|}{30} & \multicolumn{2}{|c|}{-} & \multicolumn{2}{|c|}{-} \\
\hline 4 & \multicolumn{2}{|c|}{25} & \multicolumn{2}{|c|}{13} & \multicolumn{2}{|c|}{-} & \multicolumn{2}{|c|}{-} \\
\hline 5 & \multicolumn{2}{|c|}{25} & \multicolumn{2}{|c|}{15} & \multicolumn{2}{|c|}{-} & \multicolumn{2}{|c|}{ - } \\
\hline 6 & \multicolumn{2}{|c|}{70} & \multicolumn{2}{|c|}{32} & \multicolumn{2}{|c|}{ ICSRC } & \multicolumn{2}{|c|}{20} \\
\hline 7 & \multicolumn{2}{|c|}{55} & \multicolumn{2}{|c|}{24} & \multicolumn{2}{|c|}{ ITS } & & \\
\hline 8 & & & & & & & & \\
\hline 9 & & & & & & & & \\
\hline 10 & & & & & & & & \\
\hline Total & & & & & & & & \\
\hline Mean & & & & & & & & \\
\hline $\mathrm{SD}^{* *}$ & & & & & & & & \\
\hline
\end{tabular}

* Central Venous Catheter

** Standard deviation

ISS - exit site infection; ICSRC - CVC-related bloodstream infection; ITS - subcutaneous tunnel infection

As shown in Table 3, the average presence of erythema $\leq 2 \mathrm{~cm}$ on the CVC exit site was 13.5 days, and was absent in two cases; four cases presented erythema $\leq 2 \mathrm{~cm}$ before the application of the transparent polyurethane film and five on the day or after the application of the polyurethane dressing. As for edema and pain, their occurrence is low and happened on the first two post-operative days, except for one case when they persisted since the immediate post-operative until the removal of the CVC due to subcutaneous tunnel infection. Heat was observed in two cases, both of which developed CVC-related infection.
It is also appointed in Table 3 that the mean neutropenia period was 22.7 days and that four cases developed catheter-related infection (exit site infection, subcutaneous tunnel infection and bloodstream infection). In these cases, the mean CVC dwelling time was 20.2 days.

\section{Discussion}

Allogeneic HSCT implies greater infection risk due to the rupture of skin integrity as a result of the CVC implant, presence of prolonged neutropenia due to high 
chemotherapy doses, use of immunosuppressants in the prophylaxis of graft-against-host disease, besides the need for long catheter dwelling times ${ }^{(19-20)}$.

In this study, on the average, the start of the conditioning regimen occurred two days after the catheter implant, although a study indicates that chemotherapeutic agents should not be administered until at least five to seven days after the surgery to avoid commitment of initial healing events ${ }^{(18)}$. Thus, as patients did not present an adequate platelet function due to the baseline disease and were submitted to chemotherapy with fibroblast-inhibiting agents, wound exudate continued for prolonged periods, demonstrating that healing was compromised and decreasing the efficacy of tunneling, which is the formation of fibrosis around the catheter cuff, which permits controlling the ascent of microorganisms.

The prolonged presence of exudate indicates the need to use sterile gauze dressing with adhesive tape, as the accumulation of secretion below the polyurethane dressing causes frequent additional changes, due to the risk of local microorganism proliferation. In one case, it was observed that the presence of exudate demanded the daily change of the polyurethane dressing, generating ulcerated lesions across the adhesion surface.

Additional changes of the polyurethane dressing occurred in seven cases due to the presence of dirt or detachment of the coverage. Thus, the polyurethane dressing needed additional change, hampering the dwelling time proposed in this study (seven days). These data differ from results evidenced in literature, which recommends dwelling times of more than seven days for transparent polyurethane film ${ }^{(7-8)}$.

The highest degree of skin toxicity (degree 4) was observed in three cases when polyurethane dressings were used, against only one case for sterile gauze dressings with adhesive tape. It should be highlighted that the lesions mainly affected the adhesion site of the dressing borders.

In literature, studies on skin toxicity related to the adhesion of polyurethane dressing in HSCT patients have shown controversial results. In a clinical trial, the results evidenced a statistically significant difference, with lower skin toxicity in the group with a two-day change interval in comparison with the group where dressings were changed every five days ${ }^{(7)}$. On the other hand, a study that assessed 112 patients demonstrated a statistically significant difference in the reduction of skin toxicity for the group in which dressings were changed at longer intervals (study with the same research design as the abovementioned research). Among the 32 patients who presented skin toxicity degree $\geq 2$, eight belonged to the group whose dressing was changed every 15 days and 24 to the group with dressing changes every four days $^{(8)}$.

In a study of healthy individuals with simulation of repeated applications and removals of adhesive tape for dressings or intravascular catheter fixation on integral skin, the results demonstrated epidermal alterations, leading to irritation and many points of rupture in the stratum corneum(21).

Besides this aspect, patients submitted to HSCT receive high doses of chemotherapeutic agents, which in most cases impede cell division for tissue repair. Busulphan is an agent associated with systemic dermatological toxicity, predisposing to alterations like dermatitis, erythema, dryness and cutaneous fragility, contributing to the appearance of skin toxicity on the dressing adhesion site $^{(8)}$. In the present study, that drug was used in seven cases and, in five of these, patients presented some degree of cutaneous toxicity.

Local heat is related to the presence of an inflammatory process and an objective piece of data, obtained by palpating the exit site and subcutaneous tunnel. Polyurethane dressings impede this observation, functioning as an isolating thermal barrier, without allowing the evaluator to feel local temperature differences.

Exit site erythema is a characteristic attributed to exit site infection according to the CVC-related infection criteria recommended in CDC guidelines ${ }^{(17)}$ to prevent intravascular catheter infection. In this study, a fact that can appoint this local infection was the early removal of four catheters due to CVC-related infection.

The period after the CVC implant can represent risk due to the skin trauma caused by the procedure and the delayed healing of patients submitted to HSCT, demonstrating the importance of catheter exit site care for infection prevention and control, such as the dressing type ${ }^{(22-23)}$. One preoccupying piece of information was the appearance of erythema $\leq 2 \mathrm{~cm}$ on the day or after the application of the polyurethane dressing in five cases.

In four cases under assessment, the CVC was removed early due to intravascular catheter related infection ( $D+4$ - four days after the infusion of hematopoietic stem cells, $D+6$ - six days after the infusion of hematopoietic stem cells, D+15 - 15 days after the infusion of hematopoietic stem cells and $D+20$ - 20 days after the infusion of 
hematopoietic stem cells), with two exit site infection, one subcutaneous tunnel infection and one catheter-related bloodstream infection. The appearance of infection caused an average CVC dwelling time of 20.2 days, ranging from 12 to 27 days.

On the opposite, in a retrospective study, it was identified that infection related to Hickman's catheter occurred in 10 patients (9.1\%) submitted to allogeneic HSCT and, on the average, 32 days after the implant (D+31 - 31 days after the infusion of hematopoietic stem cells). In the study, it is highlighted that Hickman catheter related infection was defined as the presence of erythema, edema, pain and/or purulent secretion on the exit site and/or in the subcutaneous tunnel associated with fever(22). Also, the research indicated that the time for the myeloid grafting (confirmed by absolute neutrophil counts of more than 500 cells $/ \mathrm{mm}^{3}$ for three days in a row) was identified as the sole risk factor for Hickman's catheter infection, with an average 18 days for the grafting.

In the present study, six cases were admitted with neutropenia (absolute granulocyte counting $\leq 1000$ cells/ $\mathrm{mm}^{3}$, without any upward trend) before the start of the conditioning regimen. This prolonged the neutropenia period, which took an average 22.7 days. Three out of four cases that developed CVC-related infection were admitted with neutropenia.

In literature, recommendations to use polyurethane dressing is based on the following aspects: decreased manipulation of exit site, diminished cost and nursing time, besides promoting patients' comfort without increasing the intravascular catheter-related infection risk $^{(6,10-11)}$. These research results diverge, however, hampering decision making in clinical practice.

In this sense, one study is observed that assessed three different type of short-term CVC dressings: sterile gauze with adhesive tape, transparent polyurethane film and highly transpiration moisture permeable transparent polyurethane film regarding the incidence of intravascular catheter-related bloodstream infection. The results appointed a statistically significant difference in the reduction of CVC related infection with the use of highly transpiration moisture permeable transparent polyurethane film changed every 72 hours(24).

On the opposite, in a randomized clinical trial conducted to compare common and highly transpiration moisture permeable transparent polyurethane film in short-term CVC, changed every 48 hours, the results evidenced similar quantities of fluid, microorganism growth in the skin culture and catheter-tip colonization among the dressing types ${ }^{(25)}$.

Hence, the recommendation to use transparent polyurethane film is controversial, mainly due to studies that demonstrated increased incidence of infection with a seven-day change interval(12-13).

The identification of Gram-positive microorganisms as causal agents of Hickman catheter-related infection indicates that the local microbiota may be related in case of CVC contamination(22-23). This shows the importance of dressing care during the healing period and formation of fibrosis around the cuff with a view to catheter exit site infection prevention and control, as there seems to exist a relation with lumen and later bloodstream contamination.

\section{Conclusions}

The results evidenced in this case series permitted inferring some observations about the use of polyurethane dressing in patients submitted to HSCT: the surgical Hickman catheter implant followed by the start of the conditioning regimen may have prolonged the healing period and the presence of exudate. This made it unfeasible to use polyurethane dressings, on the average, during the first 12 days; the transparent polyurethane film permitted constant visualization of the exit site and dressing change at longer intervals, but its additional change may have contributed to the appearance of skin toxicity; the presence of this dressing made it difficult to identify local heat; the appearance of erythema $\leq 2 \mathrm{~cm}$, a sign of exit site infection, may be related with the presence of the polyurethane dressing.

To assess the efficacy of health interventions, it is known that the "gold standard" is experimental research development, such as randomized controlled clinical trials. In view of the type of patient under analysis, however, the researchers believe that this kind of study would only be possible in a multicenter study or during an extensive data collection period. Hence, they consider that, despite the study design used (case series), the present study results offer evidence that can contribute to nursing decision making in clinical practice as to what type of coverage needs to be used in tunneled indwelling CVC dressings. 


\section{References}

1. Yazbek G, Zerati AE, Langer M, Malavolta LC, Nishinari K, Wolosker N. Utilização dos cateteres de Hickman em transplante autólogo de medula óssea: análise de 49 cateteres implantados. Acta Oncol Bras. 2002;22(3):299-305.

2. Albuquerque MP. Cirurgia dos cateteres de longa permanência (CLP) nos centros de transplante de medula óssea. Medicina. 2005;38(2):125-42.

3. Mesiano ERAB, Merchán-Hamann E. Bloodstream infections among patients using central venous catheters in intensive care units. Rev. Latino-Am. Enfermagem. 2007;15(3):453-9.

4. Hoffmann KK, Weber DJ, Samsa GP, Rutala WA. Transparent polyurethane film as an intravenous catheter dressing. JAMA. 1992;267(15):2072-6.

5. Nikoletti S, Leslie G, Gandossi S, Coombs G, Wilson R. A prospective randomized, controlled trial comparing transparent polyurethane and hydrocolloid dressings for central venous catheters. Am J Infect Control. 1999;27(6):488-96.

6. Gillies D, O'Riordan E, Carr D, O'Brien I, Frost J, Gunning R. Central venous catheter dressings: a systematic review. J Adv Nurs. 2003;44(6):623-32.

7. Rasero L, Degl'innocenti M, Mocali M, Alberani F, Boschi S, Giraudi $A$, et al. Comparison of two different protocols for central venous catheter dressing in bone marrow transplant patients: results of a randomized multicenter study. Haematologica. $2000 ; 85(3): 275-9$.

8. Benhamou E, Fessard E, Com-Nougué C, Beaussier PS, Nitenberg G, Tancrède $C$, et al. Less frequent catheter dressing changes decrease local cutaneous toxicity of highdose chemotherapy in children, without increasing the rate of catheter-related infections: results of a randomized trial. Bone Marrow Transplant. 2001;29(8):653-8.

9. Silveira RCCP, Galvão CM. O cuidado de enfermagem e o cateter de Hickman: a busca de evidências. Acta Paul Enferm. 2005; 18(3):276-84

10. Shivnan JC, McGuire D, Freedman S, Sharkazy E, Bosserman G, Larson $E$, et al. A comparison of transparent adherent and dry sterile gauze dressings for long-term central catheters in patients undergoing bone marrow transplant. Oncol Nurs Forum. 1991;18(8):1349-56.

11. Brandt B, DePalma J, Irwin M, Shogan J, Lucke JF. Comparison of central venous catheter dressing in bone marrow transplant recipients. Oncol Nurs Forum. 1996;23(5):829-36.

12. Engervall $P$, Ringertz $S$, Hagman $E$, Skogman $K$, Björkholm

$M$. Change of central venous catheter dressings twice a week is superior to once a week in patients with haematological malignances. J Hosp Infect. 1995;29(4):275-86.
13. Curchoe RM, Powers J, El-Daher N. Weekly transparent dressing changes linked to increased bacteremia rates. Infect Control Hosp Epidemiol. 2002;23(12):730-2.

14. Machado AF, Pedreira MLG, Chaud MN. Estudo prospectivo, randomizado e controlado sobre o tempo de permanência de cateteres venosos periféricos em crianças, segundo três tipos de curativos. Rev. Latino-Am. Enfermagem. 2005;13(3):291-8.

15. Machado AF, Pedreira MLG, Chaud MN. Eventos adversos relacionados ao uso de cateteres intravenosos periféricos em crianças de acordo com tipos de curativos. Rev. Latino-Am. Enfermagem. 2008;16(3):362-7

16. Pereira MG. Epidemiologia, teoria e prática. Rio de Janeiro: Guanabara Koogan; 2007.

17. Centers for Disease Control and Prevention (CDC). Guidelines for the prevention for intravascular catheter- related infections. MMWR Morb Mortal Wkly Rep. 2002;51(RR-10):1-29.

18. Payne WG, Naidu DK, Wheeler CK, Barkoe D, Mentis M, Salas RE, et al. Wound healing in patients with cancer. Eplasty. 2008;8(9):68-90.

19. Castagnola E, Molinari AC, Fratino G, Viscoli C. Conditions associated with infections of indwelling central venous catheters in cancer patients: a summary. $\mathrm{Br} \mathrm{J}$ Haematol. 2003; 121(2):233-9.

20. Zitella L. Central venous catheter site care for blood and marrow transplant recipients. Clin J Oncol Nurs. 2003;7(3):28998.

21. Tokumura F, Umekage K, Sado M, Otsuka S, Suda S, Taniguchi $M$, et al. Skin irritation due to repetitive application of adhesive tape: the influence of adhesive strength and seasonal variability. Skin Res Technol. 2005;11(2):102-6.

22. Kim DH, Bae NY, Sung WJ, Kim JG, Kim SW, Baek JH, et al. Hickman catheter site infections after allogeneic stem cell transplantation: a single-center experience. Transplant Proc. 2004;36(5):1569-73.

23. Castagnola E, Molinari AC, Giacchino M, Chiapello N, Moroni C, Caviglia I, et al. Incidence of catheter-related infections within 30 days from insertion of hickman - broviac catheters. Pediatr Blood Cancer. 2007;48(1):35-8.

24. Treston-Aurand J, Olmsted RN, Allen-Bridson K, Craig CP. Impact of dressing materials on central venous catheter infection rates. J Intrav Nurs. 1997;20(4):201-6.

25. Reynolds MG, Tebbs SE, Elliott TSJ. Do dressings with increaded permeability reduce the incidence of central venous catheter related sepsis? Intensive Crit Care Nurs. 1997;13(1):26-9.

Received: Sep. $1^{\text {st }} 2009$

Accepted: May. $3^{\text {rd }} 2010$ 